\title{
ADSORPTION OF NICKEL FROM AQUEOUS SOLUTION BY ACTIVATED CARBON PREPARED FROM WHEAT HUSK
}

\author{
Anuradha S. ${ }^{1}$, Valli Nachiyar $\mathrm{C}^{2}{ }^{2}$, Sathyamoorthy N. ${ }^{3}$ \\ ${ }^{1,2}$ Department of Biotechnology,Sathyabama University, Chennai, India \\ ${ }^{3}$ Department of Chemical engineering, Anna University, Chennai, India \\ Email: anuradhajabasingh@yahoo.in
}

\begin{abstract}
Activated carbon prepared from waste wheat husk was used to remove $\mathrm{Ni}$ (II) from aqueous solution by adsorption. Batch adsorption studies were carried out by varying the contact time, initial $\mathrm{Ni}$ (II) ion concentration in the aqueous solution, adsorbent dosage, $\mathrm{pH}$ and temperature. Maximum adsorption was observed with the $\mathrm{pH}$ of 6.0 , contact time of $4.0 \mathrm{~h}$, adsorbent dosage of $1.50 \mathrm{~g} / 150 \mathrm{ml}$ and at the temperature of $30^{\circ} \mathrm{C}$. It was indicated from the results that the effective removal of Nickel (II) ion was obtained by activating the carbon prepared from wheat husk which was heated to $600^{\circ} \mathrm{C}$.Langmuir and Freundlich isotherms were used to describe the equilibrium nature of $\mathrm{Ni}(\mathrm{II})$ adsorption. The adsorption capacity $\left(\mathrm{q}_{\mathrm{e}}\right)$ calculated from Langmuir and Freundlich isotherms were found to be $11.83 \mathrm{mg} / \mathrm{g}$ and $11.96 \mathrm{mg} / \mathrm{g}$ at pH 6.0 at $303 \mathrm{~K}$. The removal of Ni (II) was found to be $80.1 \%$ for the initial $\mathrm{Ni}$ (II) concentration of $10 \mathrm{mg} / \mathrm{l}$ and adsorbent dosage of $0.50 \mathrm{~g} / 150 \mathrm{ml}$. In the isotherm studies, the experimental adsorption data fitted well the Freundlich isotherm for the activated carbon from wheat husk. The results of the thermodynamic investigations indicate that the adsorption reactions are spontaneous $(G<0)$, slightly endothermic $(H>0)$ and irreversible $(\mathrm{S}>0)$
\end{abstract}

KEY WORDS: Nickel (II) removal, Activated carbon, Wheat husk, Adsorption isotherm, Thermodynamics

\section{INTRODUCTION}

The presence of heavy metals in the environment can be detrimental to the living species. Despite strict environmental regulations, significant quantities of heavy metals are found in the wastewaters from several industries such as non ferrous metal, electroplating, porcelain enameling, silver refining, welding, alloy manufacturing and fertilizer industry. The heavy metals are trace metals with density at least five times that of water. They are sTable- elements and are bioaccumulative in their nature. They include mercury, nickel, lead, arsenic, cadmium, chromium, aluminium, platinum, zinc, silver and gold (1).

Nickel is highly toxic and is present in the waste waters of industries such as paper and pulp, fertilizer, silver refining, pigments and coatings, basic steel work foundry, automobile, petroleum refining(2). The most likely sources of nickel emissions are found to be from metallurgical plants (3), engines burning fuel containing nickel additives, plating plants (4), and incineration of nickel products, metal extraction, fabrication operation and effluent from nickelcadmium battery industries (5). The target tissues affected by nickel include skin, larynx, nasal passages and lungs. The signs and symptoms of nickel exposure include blue colored lips, cancer of lungs, nasal cavity and larynx, contact dermatitis, fever, headache, dizziness, skin rashes and vomiting (6). The incidence of lung and nasopharyngeal cancer in occupationally exposed population is due to the carcinogenic effect of nickel (7). Nickel in its ionic form can cross the cell membrane and get deposited in the nucleus. It might thus be the initiator and promoter of cancer. The World Health Organization (WHO) recommended a maximum accepTableconcentration of $\mathrm{Ni}(\mathrm{II})$ in drinking water as $0.05 \mathrm{mg} / \mathrm{l}$ per $\mathrm{kg}$ of the body weight per day and the inhalation should not exceed $3.5 \times 10^{-6} \mathrm{mg} / \mathrm{m}^{3}(1)$.

Many methods like chemical precipitation (8), ion exchange (9), reverse osmosis, electro dialysis (4), membrane separation (10) and adsorption (11) are available for the removal of nickel present in the industrial effluents. Each has its own merits and demerits in application. The selection of the treatment method is based on the concentration of metal ion in the wastewater stream and the cost of the treatment (12). Currently, chemical precipitation is the most widely used technique. However, particular frustrating aspects of this method are significant sludge production, the ever-increasing cost of the landfill for the disposal and most importantly the longterm environmental consequences. These aspects result in an overall cost escalation of the process (13). Ion exchange, reverse osmosis and electro dialysis have material and operational cost $(4,8)$. Among these techniques, adsorption is one of the most commonly used methods due to its high efficiency and easy operation (14). In recent years, a number of adsorbents such as iron coated sand, iron coated granular activated carbon (15), modified chitin (16), fly ash (17), low grade bituminous coal (18), wool carbonizing waste (19), rice husk (20), kaolinite (12), Zeolite (21), paper mill sludge (17), bagasse (22), green algae $(23,24)$, bone char (25) and Lignite (26) was used in the heavy metal removal from effluents. In the present work, wheat husk was taken for the preparation of 
activated carbon and its applicability in the removal of nickel ions present in the wastewater was studied. This paper reports the effect of adsorption parameters such as $\mathrm{pH}$, contact time, initial concentration, and adsorbent dosage on the percentage removal of nickel (II) ions by using Activated Carbon prepared from Wheat Husk (ACWH) as the adsorbent material.

\section{METHODS}

\section{A. Preparation of adsorbent}

The wheat husk was washed with 11 of deionised water and rinsed with $200 \mathrm{ml}$ of $1 \% \mathrm{HCl}$. The wheat husk was dried at $30^{\circ} \mathrm{C}$ for $24 \mathrm{~h}$. The dried wheat husk was mixed with phosphoric acid at a ratio of $1: 3(\mathrm{w} / \mathrm{w})$ and soaked for $48 \mathrm{~h}$, so that the reagents were fully adsorbed onto the raw material. The mixture was drained and dried at $108^{\circ} \mathrm{C}$ for $1 \mathrm{~h}$. The dried husk samples were carbonized at $400^{\circ} \mathrm{C}$ in a muffle furnace for $1 \mathrm{~h}$. The carbons prepared were washed repetitively with distilled water to recover the acid and then $1 \% \mathrm{NaHCO}_{3}$ solution to remove the residual acid. The wheat husk thus prepared was dried at $30^{\circ} \mathrm{C}$ for 2 $\mathrm{h}$ and then powered and sieved. The powered material remaining between 50 and 100 mesh $(150 \mu \mathrm{m})$ was utilized for the adsorption studies. The proximate analysis of the raw material and the activated carbon properties are given in Table-1. The adsorbent obtained is termed as 'ACWH'.

Table 1. Physical and chemical properties of adsorbent used in adsorption experiments

\begin{tabular}{|l|c|}
\hline Surface area $\left(\mathrm{m}^{2} \mathrm{~g}^{-1}\right)$ & 1563.94 \\
\hline Bulk density $\left(\mathrm{g} \mathrm{cm}^{-3}\right)$ & 0.42 \\
\hline Particle size $(\mu \mathrm{m})$ & 150 \\
\hline Ash $(\%)$ & 3.65 \\
\hline Carbon $(\%)$ & 29.5 \\
\hline Moisture (1\%) & 9.35 \\
\hline Volatile $(\%)$ & 57.42 \\
\hline lodine number $\left(\mathrm{mg} \mathrm{g}^{-1}\right)$ & 825.31 \\
\hline Methylene blue number $\left(\mathrm{mg} \mathrm{g}^{-1}\right)$ & 280.00 \\
\hline
\end{tabular}

\section{B. Preparation of Adsorbate}

All the reagents used were of analytical grade. $\mathrm{Ni}$ (II) stock solution was prepared by dissolving $4.479 \mathrm{~g}$ of pure nickel sulphate $\left(\mathrm{NiSO}_{4} \cdot 6 \mathrm{H}_{2} \mathrm{O}\right)$ in $1 \mathrm{l}$ of double distilled water. The $\mathrm{pH}$ of solution was adjusted by adding $0.1 \mathrm{~N}$ sulphuric acid or $0.1 \mathrm{~N} \mathrm{NaOH}$. Adsorption experiments were conducted by using ACWH as adsorbent.

\section{Adsorption experiments using ACWH}

Batch adsorption experiments were carried out at $30^{\circ} \mathrm{C}$ on a rotary shaker at $186 \mathrm{rpm}$ using capped $250 \mathrm{ml}$ Erlenmeyer flasks for various contact times. Adsorption studies involving nickel (II) ions on ACWH was conducted by taking different amounts of adsorbent like $0.15,0.30$, $0.60,0.90$ and $1.5 \mathrm{~g}$ for $150 \mathrm{ml}$ of $10,20,30,40$, and $50 \mathrm{mg} / \mathrm{l}$ nickel solutions. Experiments were carried out at various $\mathrm{pH}$ values of nickel (II) solution adjusted with $\mathrm{NaOH}$ and $\mathrm{HCl}$ solutions using $\mathrm{pH}$ meter. The contact time was varied from 30 to $300 \mathrm{~min}$. At the end of contact period, the reaction mixture was centrifuged at 56,000 rpm for $10 \mathrm{~min}$. Nickel (II) in the supernatant was analyzed by using visible spectrophotometer using procedure given by (27) at $540 \mathrm{~nm}$. The percentage removal of nickel (II) was calculated from the differences between the concentrations of $\mathrm{Ni}$ (II) before and after adsorption.

\section{D.Isotherm experiments}

Isotherm studies were carried out in a series of $250 \mathrm{ml}$ Erlenmeyer flask filled with $150 \mathrm{ml}$ of $\mathrm{Ni}$ (II) solution having different initial concentrations with the $\mathrm{pH}$ of 6.0 . After the equilibrium time, the solution was separated and analyzed. The initial concentrations of solutions taken for studies were 10, 20, 30, 40 and $50 \mathrm{mg} / \mathrm{l}$, using adsorbent dosage of $1.5 \mathrm{~g} / 150 \mathrm{ml}$ solution. Adsorption studies were carried out at different temperatures to obtain equilibrium isotherms. The equilibrium adsorption capacity was calculated using

$$
\mathrm{q}_{\mathrm{e}}=\frac{\left(\mathrm{C}_{0}-\mathrm{C}_{\mathrm{e}}\right)}{\mathrm{M}} \times \mathrm{V}
$$

where $q_{e}(\mathrm{mg} / \mathrm{g})$ is the equilibrium adsorption capacity, $C_{0}$ and $\mathrm{C}_{\mathrm{e}}$ are the initial and equilibrium concentrations of $\mathrm{Ni}$ (II) ions in solution. V (I) is the volume of the solution and $\mathrm{M}$ (g) is the weight of adsorbent.

\section{RESULTS AND DISCUSSION}

\section{A. Effect of contact time on the percentage removal of $\mathrm{Ni}$ (II)} ions

The effect of contact time on the percentage removal of $\mathrm{Ni}$ (II) on $\mathrm{ACWH}$ was studied at $30^{\circ} \mathrm{C}$ by varying the contact time from 30 to $300 \mathrm{~min}$ for $\mathrm{Ni}$ (II) solution having initial concentration from $10 \mathrm{mg} / \mathrm{l}$ to $50 \mathrm{mg} / \mathrm{l}$. 


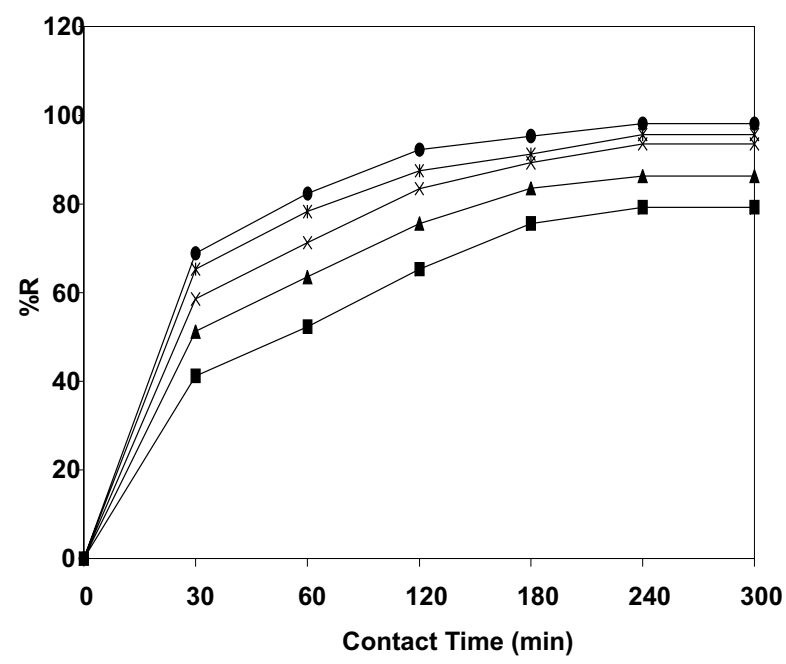

Fig. 1. Effect of Contact time on the Percentage Removal of $\mathrm{Ni}$ (II) ions by ACWH at different dosages

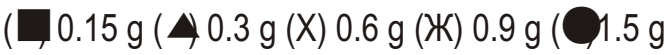

The study was made for adsorbent dosages ranging from $0.15 \mathrm{~g}$ to $1.5 \mathrm{~g}$ for $150 \mathrm{ml}$ of $10 \mathrm{mg} / \mathrm{l} \mathrm{Ni}$ (II) solution with the $\mathrm{pH}$ of 6.0 and at $30^{\circ} \mathrm{C}$ and the result is shown in the Fig 1.The percentage removal of $\mathrm{Ni}$ (II) ions was calculated using the formula given below

$$
\% R=\frac{\left(C_{0}-C_{t}\right)}{C_{0}} \times 100
$$

where $\% \mathrm{R}$ is the percentage removal of $\mathrm{Ni}(\mathrm{II})$ ions in solution. The amount of $\mathrm{Ni}$ (II) ions adsorbed was found to increase with increase in the contact time and attained equilibrium at $4 \mathrm{~h}$ for all the concentrations of $\mathrm{Ni}$ (II) ions studied. The Ni (II) ion adsorption increases initially and approaches a constant value gradually as the equilibrium is attained. This behavior is attributed to the relatively less available adsorption sites on the surface of the ACWH as contact time increases (4).

\section{B. Effect of $p H$ on the percentage removal of $\mathrm{Ni}$ (II) ions}

Adsorption experiments were carried out using Ni (II) solutions at different $\mathrm{pH}$ values by maintaining the adsorbent dosage as $1.50 \mathrm{~g} / 150 \mathrm{ml} \mathrm{Ni}$ (II) solution at $30^{\circ} \mathrm{C}$ for initial concentration of $\mathrm{Ni}$ (II) solution ranging from $10 \mathrm{mg} / \mathrm{l}$ to 50 $\mathrm{mg} / \mathrm{l}$. The effect of $\mathrm{pH}$ on the percentage removal of $\mathrm{Ni}$ (II) ions is shown in Fig.2. The $\mathrm{Ni}$ (II) ion adsorption was found to increase from $\mathrm{pH}$ of 2.0 to 6.0 , after which the metal ion uptake remained constant. The reduced uptake of metal ion at lower $\mathrm{pH}$ was due to the high concentration of $\mathrm{H}^{+}$and free $\mathrm{Ni}$ (II) ions present in the solution that offered a competitive adsorption for the adsorption sites on the surface area of the ACWH. However, above the $\mathrm{pH}$ range of 6.0 , the nickel hydroxide species started to precipitate and thereby clogged the pores ofACWH. Similar observations were reported by (15).

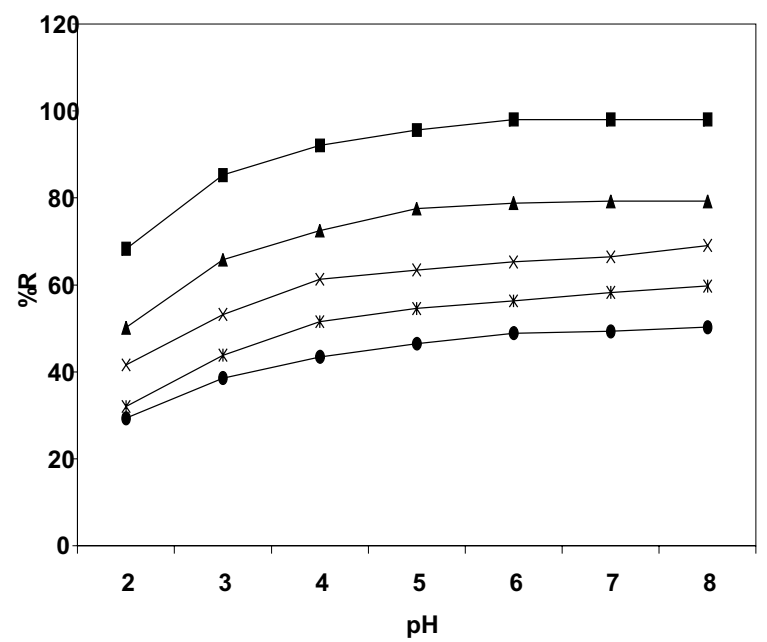

Fig. 2. Effect of $\mathrm{pH}$ on the Percentage Removal of $\mathrm{Ni}$ (II) ions by ACWH ml dosage ( $10 \mathrm{mg} / \mathrm{l}$ ( $420 \mathrm{mg} / \mathrm{l}$ (X)

$$
30 \mathrm{mg} / \mathrm{l} \text { (Ж) } 40 \mathrm{mg} / \mathrm{l} \text { (O) } 50 \mathrm{mg} / \mathrm{l}
$$

The percentage removal of $\mathrm{Ni}$ (II) ions increased from $68.3 \%$ to $98.1 \%$ and $29.3 \%$ to $50.3 \%$ for initial concentration of $\mathrm{Ni}$ (II) solutions $10 \mathrm{mg} / \mathrm{l}$ and $50 \mathrm{mg} / \mathrm{l}$ respectively for a fixed adsorbent dosage of $1.5 \mathrm{~g}$ at $30^{\circ} \mathrm{C}$ as the $\mathrm{pH}$ of the $\mathrm{Ni}$ (II) solution was varied from 2.0 to 8.0.This is due to the surface complexation reaction, which is influenced by electrostatic force of attraction between $\mathrm{Ni}$ (II) ions and surface of ACWH. Ni (II) has lower charge density, higher electro negativity of 1.8 and larger ionic radius of $0.069 \mathrm{~nm}$ which shows favorability to electrostatic force of attraction (28). The optimum pH was chosen to be 6.0 for further adsorption studies.

C. Effect of adsorbent dosage on the percentage removal of $\mathrm{Ni}$ (II) ions

Adsorbent studies were carried out using ACWH dosages ranging from $0.3 \mathrm{~g}$ to $1.80 \mathrm{~g}$ in $\mathrm{Ni}$ (II) ion concentration $10 \mathrm{mg} / \mathrm{l}, 20 \mathrm{mg} / \mathrm{l}, 30 \mathrm{mg} / \mathrm{l}, 40 \mathrm{mg} / \mathrm{l}$ and 50 $\mathrm{mg} / \mathrm{f}$ for the equilibrium time of $4 \mathrm{~h}$ at optimum $\mathrm{pH} 6.0$ and at $30^{\circ} \mathrm{C}$. The effect of adsorbent dosage on the percentage removal is shown in Fig. 3. It was found that the surface area available for the adsorption is limited for a specific dosage of ACWH. The reduced adsorption of $\mathrm{Ni}$ (II) ions at high concentration was mainly due to the unavailability of adsorption sites. It is clear from the Fig. 3 that the percentage removal can be increased from 80.1 to 98.1 , if the adsorbent dosage is increased from $0.15 \mathrm{~g}$ to $1.5 \mathrm{~g}$ for $150 \mathrm{ml}$ of $\mathrm{Ni}$ (II) solution at $10 \mathrm{mg} / \mathrm{l}$ concentration. This is due to the availability of more binding sites for complexation of nickel (II) ions (29). However, increasing the adsorbent dosage above $1.5 \mathrm{~g}$ had very little influence on the percentage removal which was just about 0.004 at 
equilibrium for $1.8 \mathrm{~g}$ of $\mathrm{ACWH}$. This effect may be due to the decline in the $\mathrm{Ni}$ (II) ion in the solution with the increase in the adsorbent dosage. Hence further addition of ACWH above $1.50 \mathrm{~g}$ in $150 \mathrm{ml}$ solution was considered to be economically unsuiTable- for the removal of $\mathrm{Ni}$ (II) ions. At lower $\mathrm{Ni}$ (II) ion concentration the available sites of adsorption on the adsorbent is more, hence percentage removal was found to be high. Whereas at high concentrations, the available sites of adsorption become fewer, hence the percentage removal was found to be low.

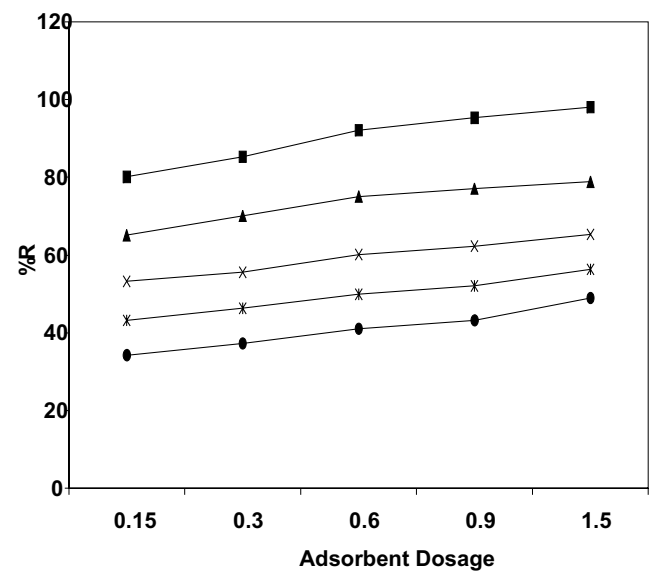

Fig. 3. Effect of Adsorbent Dosage on the Percentage Removal of $\mathrm{Ni}$ (II) ions at different Concentrations ( $\square, 10$ mg/l ( 20 mg/l (X) 30 mg/l (Ж) 40 mg/l (C50 mg/l

The adsorption density which was $6.54 \mathrm{mg} / \mathrm{g}$ for ACWH dosage of $1.5 \mathrm{~g}$ decreased to $5.45 \mathrm{mg} / \mathrm{g}$ for $1.8 \mathrm{~g}$. This indicates that as the adsorbent dosage is increased above $1.5 \mathrm{~g} / 150 \mathrm{ml}$ of $\mathrm{Ni}$ (II) solution, the adsorption density got lowered. Therefore, adsorbent dosage of $1.5 \mathrm{~g}$ was taken as optimum for further studies.

\section{$D$. Effect of initial concentration on the percentage removal of Ni (II) ions}

As the initial concentration of $\mathrm{Ni}$ (II) ion provides an important driving force to overcome the Mass Transfer resistance between aqueous and solid phases (6), adsorption experiments were conducted using $\mathrm{ACWH}$ with different initial concentrations of $\mathrm{Ni}(\mathrm{II})$ ions for $4 \mathrm{~h}$, at the $\mathrm{pH}$ of 6.0. The effect of initial $\mathrm{Ni}$ (II) ion concentration on the percentage removal is shown in the Fig. 4. The plot represents the percentage removal of $\mathrm{Ni}$ (II) ions versus the initial $\mathrm{Ni}$ (II) ion concentration for an equilibrium time of $4 \mathrm{~h}$. The plot reveals that increasing the initial $\mathrm{Ni}$ (II) ion concentration from $10 \mathrm{mg} / \mathrm{l}$ to $50 \mathrm{mg} / \mathrm{l}$ decreases the percentage removal of $\mathrm{Ni}$ (II) ions from $80.1 \%$ to $34.2 \%$. The rate of percentage removal of $\mathrm{Ni}$ (II) ions is higher in the beginning due to a larger surface area of ACWH being available for the adsorption of metal ions. After the adsorbed materials forms a thick layer, the capacity of the adsorbent gets exhausted and then the uptake rate is controlled by the rate of transport of sorbate from the exterior to the interior sites of the adsorbent particles.

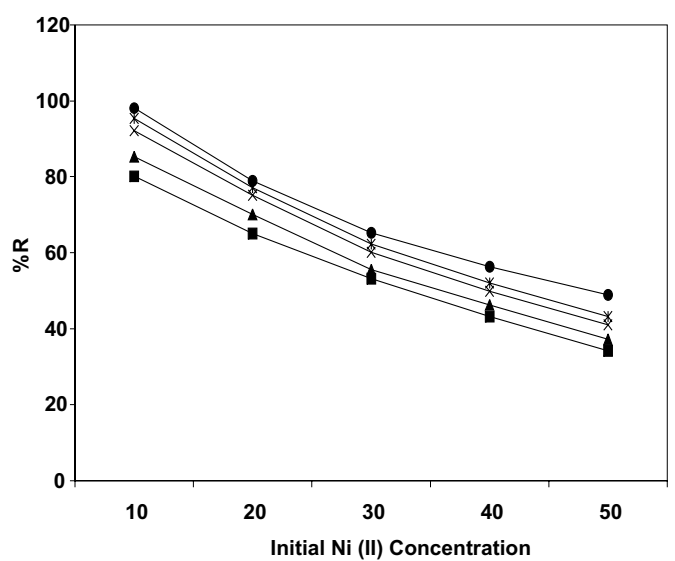

Fig. 4. Effect of Initial Ni (II) ion concentration on the Percentage Removal by AWHV at different Dosage

$$
0.15 \mathrm{~g}(40.3 \mathrm{~g}(\mathrm{X}) 0.6 \mathrm{~g} \text { (Ж) } 0.9 \mathrm{~g} \text { (C) } 1.5 \mathrm{~g}
$$

The percentage removal of $\mathrm{Ni}$ (II) ions is greater at lower initial concentration than at higher initial concentrations. This may be due to the fact that the surface area available for adsorption is limited for a specific dosage of activated carbon. The excess amount of $\mathrm{Ni}$ (II) ion in the solution is less adsorbed due to the unavailability of adsorption sites (30).

\section{E. Effect of temperature on the percentage removal of $\mathrm{Ni}$ (II) ions}

The effect of temperature on the adsorption of $\mathrm{Ni}$ (II) ions at different concentrations by ACWH at $1.50 \mathrm{~g} / 150 \mathrm{ml}$ is shown in Fig. 5.

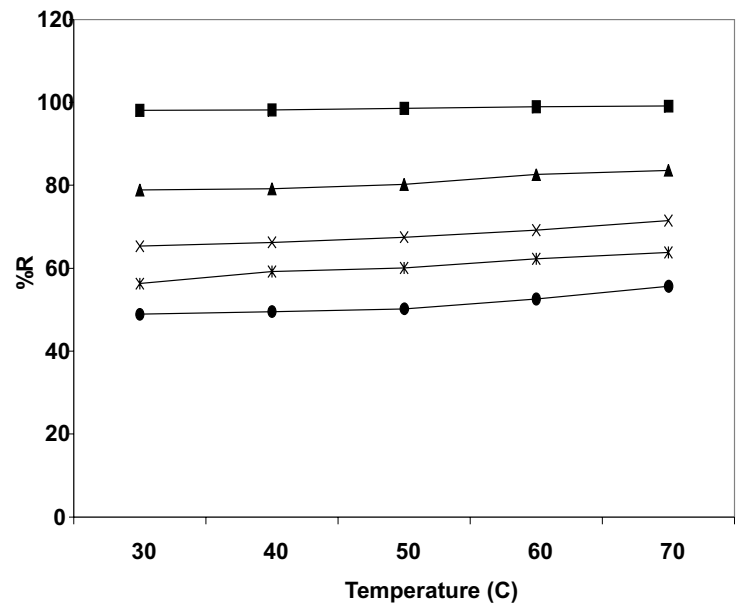

Fig. 5. Effect of Temperature on the Percentage Removal of $\mathrm{Ni}(\mathrm{II})$ ion at different Concentrations by ACWH ( $\square, 10$ mg/l ( 420 mg/l $\quad$ (X) 30 mg/l $\quad$ (Ж) 40 mg/l (C) 50 mg/l 
The results reveal that the adsorption capacity increased from $10.52 \mathrm{mg} / \mathrm{g}$ to $12.26 \mathrm{mg} / \mathrm{g}$ as the temperature increased from $30^{\circ} \mathrm{C}$ to $70^{\circ} \mathrm{C}$ for an initial concentration of $20 \mathrm{mg} / \mathrm{l}$ at $\mathrm{pH} 6.0$ for an optimum time of 4 h. This indicates that the adsorption of $\mathrm{Ni}$ (II) ions on $\mathrm{ACWH}$ is an endothermic process. The increase in temperature increases the mobility of the cation. The increase of adsorption capacity at increased temperature indicated that the adsorption of $\mathrm{Ni}$ (II) ions by ACWH might involve not only physical but also chemical sorption. This effect may be due to the fact that at higher temperatures an increase in the active sites occurs due bond rupture (24). The standard Gibbs free energy was evaluated by

$$
\text { ? } \mathrm{G}^{\prime}=-\mathrm{RT} \ln \mathrm{K}_{\mathrm{c}}
$$

The equilibirium constant $\mathrm{K}_{\mathrm{c}}$ was evaluated at each temperature using

$$
\mathrm{K}_{\mathrm{c}}=\frac{\mathrm{C}_{\mathrm{Be}}}{\mathrm{C}_{\mathrm{Ae}}}
$$

where $\mathrm{C}_{\mathrm{Be}}$ and $\mathrm{C}_{\mathrm{Ae}}$ are the equilibrium concentration of $\mathrm{Ni}$ (II) ions on ACWH and solutions respectively. Van't Hoff equation was used to determine the standard enthalpy (? H') and entropy (? S')

$$
\ln \mathrm{K}_{\mathrm{c}}=\frac{(\text { ? S') }(\text { ? H') }}{\mathrm{R}^{2} \mathrm{~T}}[5]
$$

? H' and ? S' were obtained from the slope and intercept of plot of $\mathrm{In} \mathrm{K}_{\mathrm{c}}$ versus 1/T as shown in Fig. 6 and listed in Table- 2. Values of free energy changes ? G' are negative, conforming the adsorption of $\mathrm{Ni}$ (II) on ACWH is thermodynamically favorable. As the temperature increases, the ? G' value increases indicating more driving force and hence resulting in larger adsorption capacity at higher temperatures. The values of? H' are positive, indicating that the adsorption process is endothermic in nature. The negative values of ? S' indicate greater order of reaction during adsorption of $\mathrm{Ni}$ (II) on the ACWH surface.

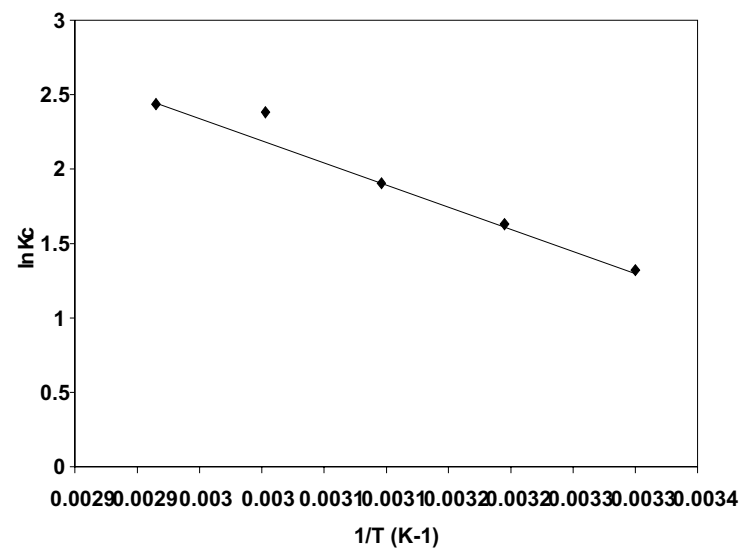

\begin{tabular}{|c|c|c|c|}
\hline $\begin{array}{c}\mathrm{T} \\
(\mathrm{K})\end{array}$ & $\begin{array}{c}\triangle \mathrm{G}^{0} \\
\left(\mathrm{~kJ} \mathrm{~mol}^{-1}\right)\end{array}$ & $\begin{array}{c}\triangle \mathrm{H}^{0} \\
\left(\mathrm{~kJ} \mathrm{~mol} \mathrm{~mol}^{-1}\right)\end{array}$ & $\begin{array}{c}\triangle \mathrm{S}^{0} \\
\left(\mathrm{~J} \mathrm{~mol} \mathrm{l}^{-1} \mathrm{~K}^{-1}\right)\end{array}$ \\
\hline 303 & -3.33 & \multirow{5}{*}{+25.84} & \multirow{5}{*}{+96.28} \\
\hline 313 & -4.24 & & \\
\hline 323 & -5.12 & & \\
\hline 333 & -6.59 & & \\
\hline 343 & -6.95 & & \\
\hline
\end{tabular}

Fig. 6. Van't Hoff plot for the Adsorption of $\mathrm{Ni}$ (II) ions at $20 \mathrm{mg} / \mathrm{l}$ by ACWH at $1.5 \mathrm{~g} / 150 \mathrm{ml}$

Table 2. Thermodynamic properties for the adsorption of $\mathrm{Ni}$ (II) onto ACWH

F. Adsorption isotherm studies

The distribution of $\mathrm{Ni}$ (II) ions between $\mathrm{ACWH}$ and the $\mathrm{Ni}$ (II) solution, when the system is at equilibrium is used to determine the maximum adsorption capacity of ACWH. Models that are most widely used for solid-liquid adsorption are Langmuir and Freundlich models.

\section{Langmuir isotherm}

Langmuir equation, used for fitting equiliubrium data is given by

$$
q_{e}=\frac{K_{L} C_{e}}{1+a_{L} C_{e}}
$$

The amount of $\mathrm{Ni}$ (II) ion adsorbed at equilibrium per unit mass of the adsorbent is given by the above equation, where

$$
a_{L}=\frac{K_{L}}{X_{m}}
$$


The linear form of Langmuir isotherm is given by

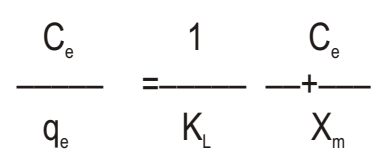

where $K_{L}(I / g)$ and $a_{L}(l / m g)$ represent Langmuir constants. The maximum adsorption capacity in Langmuir model $X_{m}(\mathrm{mg} / \mathrm{g})$ is given by

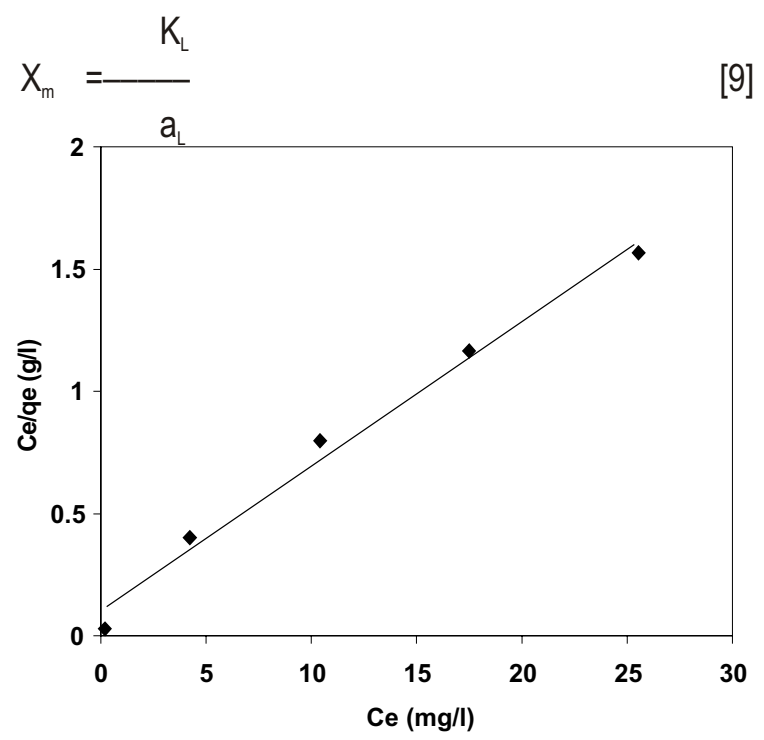

Fig.7 Langmuir Adsorption Isotherm for ACWH at 1.5

$$
\mathrm{g} / 150 \mathrm{ml}
$$

The linear plot of $C_{e} / q_{e}$ versus $C_{e}$ confirms that Langmuir model can be applied for the $\mathrm{Ni}$ (II) ion adsorption onto ACWH. The Langmuir isotherm is shown in Fig. 7.

The Langmuir constants were calculated from the slope and intercept of this plot and are given in Table- 3. The effect of isotherm shape has been considered with a view to predict whether the adsorption is favorable or unfavorable. The essential features of Langmuir isotherm can be expressed in terms of a dimensionless equilibrium parameter

$$
\mathrm{R}_{\mathrm{L}}=\frac{1}{1+\mathrm{a}_{\mathrm{L}} \mathrm{C}_{0}}
$$

Values of $R_{L}$ are shown in Table- 4. for Ni (II) ion adsorption onto ACWH for various initial $\mathrm{Ni}$ (II) ion concentrations. Values of $R_{L}$ between 0 and 1 indicate favorable adsorption. The $R_{\llcorner}$values obtained indicate that adsorption is favorable for the entire initial $\mathrm{Ni}$ (II) ion concentrations studied and that it is more favorable at low Initial concentration of Nickel (II) ions in the solution.

Table 3. Langmuir and Freundlich parameters for the adsorption of $\mathrm{Ni}$ (II) onto $\mathrm{ACWH}$ at $30^{\circ} \mathrm{C}$ ions

\begin{tabular}{|c|c|c|c|c|c|c|c|c|}
\hline \multirow{2}{*}{$\begin{array}{c}\mathrm{T} \\
\left(^{\circ} \mathrm{C}\right)\end{array}$} & \multicolumn{3}{|c|}{ Langmuir constants } & \multicolumn{4}{c|}{ Freundlich constants } \\
\cline { 2 - 9 } & $\begin{array}{c}\mathrm{q}_{\mathrm{eL}} \\
\left(\mathrm{mg} \mathrm{g}^{-1}\right)\end{array}$ & $\mathbf{X}_{\mathrm{m}}$ & $\begin{array}{c}\mathrm{a}_{\mathrm{L}} \\
\left(\mathrm{mg}^{-1}\right)\end{array}$ & $\mathbf{R}^{2}$ & $\begin{array}{c}\mathrm{q}_{\text {ef }} \\
\left(\mathrm{mg} \mathrm{g}^{-1}\right)\end{array}$ & $1 / \mathbf{n}$ & $\mathrm{K}_{\mathrm{f}}$ & $\mathbf{R}^{2}$ \\
\hline 30 & 11.83 & 16.89 & 0.553 & 0.9874 & 11.96 & 0.246 & 7.380 & 0.9991 \\
\hline
\end{tabular}

\section{Freundlich isotherm}

The Freundlich isotherm gives the relationship between equilibrium liquid and adsorbent capacity based on multilayer adsorption. This isotherm is widely used in adsorption studies at low concentrations of solute in aqueous medium. The expression for Freundlich equation is given by

$$
\mathrm{q}_{\mathrm{e}}=\mathrm{K}_{\mathrm{f}} \mathrm{C}_{\mathrm{e}}^{1 / n}
$$

The linear form of Freundlich equation is given by

$$
\ln \mathrm{q}_{\mathrm{e}}=\ln \mathrm{K}_{\mathrm{f}}+1 / \ln \left(\ln \mathrm{C}_{\mathrm{e}}\right)
$$

where $K_{f}(\mathrm{mg} / \mathrm{g})$ and $n$ are multilayer adsorption capacity and intensity of adsorption respectively. These constants are given in Table- 3.According to (31), values of $\mathrm{n}$ between 1 and 10 represent beneficial adsorption. The Freundlich adsorption isotherm is shown is Fig. 8.

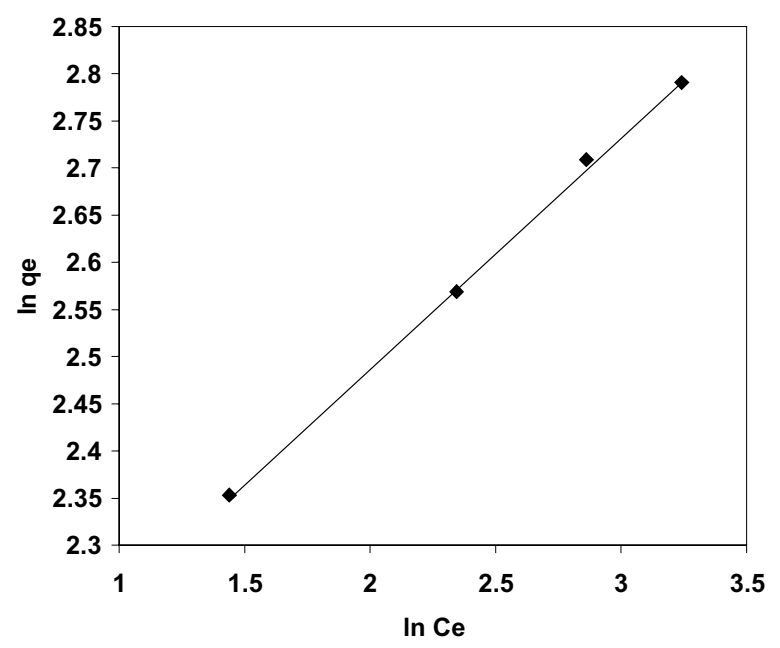

Fig. 8. Freundlich Adsorption Isotherm for ACWH at 1.5 $\mathrm{g} / 150 \mathrm{ml}$ 
Table 4. Values of $\mathbf{R}_{\mathrm{L}}$ and the comparison of experimental and predicted values of qe from adsorption isotherms

\begin{tabular}{|c|c|c|c|}
\hline $\begin{array}{c}\mathbf{q}_{\mathrm{e}} \\
\left(\mathbf{m g ~ g}^{-1}\right)\end{array}$ & $\begin{array}{c}\mathbf{q}_{\mathrm{el}} \\
\left(\mathbf{m g ~ g}^{-1}\right)\end{array}$ & $\begin{array}{c}\mathbf{q}_{\mathrm{ef}} \\
\left(\mathbf{m g ~ g}^{-1}\right)\end{array}$ & $\mathbf{R}_{\mathbf{L}}$ \\
\hline 6.54 & 1.612 & 4.909 & 0.153 \\
\hline 10.52 & 11.87 & 10.51 & 0.083 \\
\hline 13.06 & 14.45 & 13.12 & 0.056 \\
\hline 15.01 & 15.37 & 14.90 & 0.043 \\
\hline 16.30 & 15.84 & 16.35 & 0.035 \\
\hline
\end{tabular}

A comparison of the experimental values and predicted values from adsorption isotherms is shown in Fig. 9 and listed in Table- 4 .

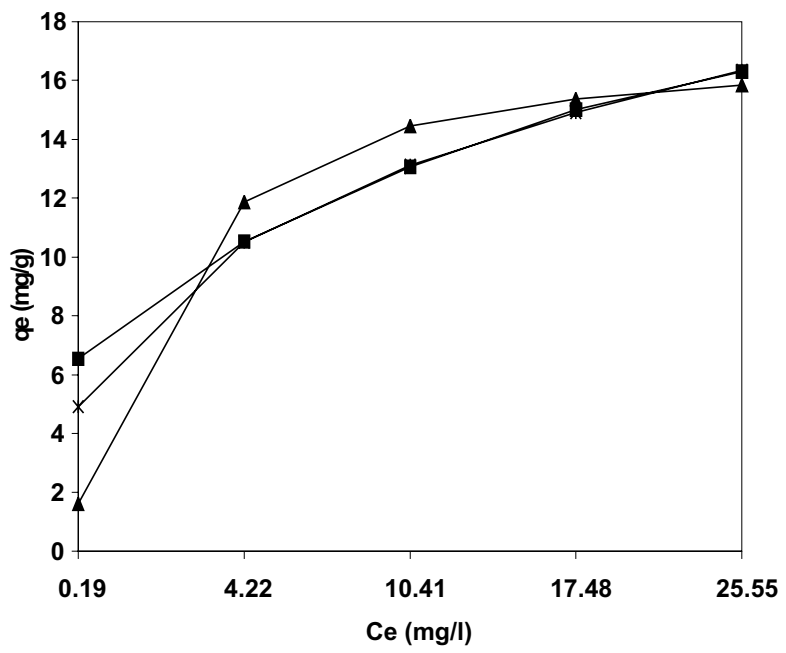

Fig.9 Experimental and predicted values of $\mathrm{q}_{\mathrm{e}}$ from adsorption isotherm for ACWH at $1.5 \mathrm{~g} / 150 \mathrm{ml}$

The error percentages between the experimental and predicted values of $\mathrm{q}_{\mathrm{e}}$ from Langmuir model and Freundlich model are calculated using

$$
\sum\left(q_{e, e x p}-q_{e, c a l}\right) / q_{e, e x p}
$$$$
I=1
$$

Error $\%=\frac{1=1}{N} \times 100$

The error percentages are found to be $7.182 \%$ and $1.613 \%$. The Freundlich model agrees well with experimental data considering that the obtained percentage error values are lower than $2.0 \%$. Table- 5 gives the comparison of $\mathrm{Ni}$ (II) removal by Activated Carbon prepared from Wheat husk $(\mathrm{ACWH})$ and other adsorbents found in literature.It also provides the adsorption capacities of different adsorbents for the removal of $\mathrm{Ni}(\mathrm{II})$ ions.
Table 5.Comparison of Ni (II) removal by ACWH and other adsorbents found in literature

\begin{tabular}{|c|c|c|}
\hline Adsorbent & $\begin{array}{c}\text { Adsorbent } \\
\text { capacity } \\
\left(\mathbf{m g ~ g}^{-1}\right)\end{array}$ & References \\
\hline Fly ash & 0.03 & {$[9]$} \\
\hline Bagasse & 0.001 & {$[9]$} \\
\hline Carbon aerogel & 12.875 & {$[6]$} \\
\hline Waste tea & 18.42 & {$[11]$} \\
\hline BakerÜsyeast & 11.40 & {$[3]$} \\
\hline $\begin{array}{c}\text { Sheep manure } \\
\text { waste }\end{array}$ & 7.20 & {$[30]$} \\
\hline Turkish fly ash & 1.16 & {$[31]$} \\
\hline ACWH & 11.86 & $\begin{array}{c}\text { Present } \\
\text { study }\end{array}$ \\
\hline
\end{tabular}

IV.CONCLUSION

The present work shows that the wheat husk activated carbon prepared by using phosphoric acid as the activating agent can be effectively employed for the adsorption of Nickel (II) ions. Nickel adsorption was found to be dependent on $\mathrm{pH}$, adsorbent dosage and initial nickel ion concentration. Adsorption follows the Freundlich model. According to these results, Maximum adsorption was observed at $\mathrm{pH}$ of 6.0 , contact time of $4.0 \mathrm{~h}$, adsorbent dosage of $1.50 \mathrm{~g} / 150 \mathrm{ml}$ and at temperature of $30^{\circ} \mathrm{C}$. This indicates that the adsorbent prepared from wheat husk can be used in the attempt for the removal of other heavy metal ions from waste water.

\section{REFERENCES}

[1] Dee Snell, F.,Hilton, C.L., Ettre, L.S.,1967, Encyclopedia of industrial chemical analysis, Interscience publishers, pp. 431.

[2] Sheng,P.X., Ting,Y.P., Chen,J.P., Hong,L., 2004, Sorption of lead, copper, cadmium, zinc and nickel by marine algal biomass: characterization of biosorptive capacity and investigation of mechanisms, Journal of Colloid and Interface Science, 275, pp.131-141.

[3] Padmavathy, V., Vasudevan, P., Dhingra, S.C., 2003, Biosorption of nickel (II) ions on Baker's yeast, Process Biochemistry.38, pp.1389-1395.

[4] Hasar, H., 2003, Adsorption of nickel (II) from aqueous solution on to activated carbon prepared from almond husk,Journal of Hazardous Materials, 97, pp. 49-57. 
[5] Kadirvelu, K., Brasquet, B., Le Cloirec, P., 2000, Removal of $\mathrm{Cu}$ (II), $\mathrm{Pb}$ (II) and $\mathrm{Ni}$ (II) by adsorption onto activated carbon cloth, Langmuir, 16,pp.8404-8409.

[6] Meena, A.K., Mishra, G.K., Rai, P.K., Rajagopal, C., Nagar, P.N., 2005, Removal of heavy metal ions by using carbon aerogel as an adsorbent, Journal of Hazardous Materials, 122,pp.161-170.

[7] Smith-Sivertsen, T., Lund, E., Thomassen, Y., Norseth T., 1997, Human nickel exposure in an area polluted by nickel refining, The Sor-Varanger study. Archives of Environmental Health, 52, pp.464-471.

[8] Remoudaki, E., Hatzikioseyian, A., Kousi, P., Tsezos M., 2003, The mechanism of metal precipitation by biologically generated alkalinity in biofilm reactors, Water Research, 6, pp.3843-3854.

[9] Rao, M., Parwate, A.V., Bhole, A.G., 2002, Removal of $\mathrm{Cr}^{6+}$ and $\mathrm{Ni}^{2+}$ from aqueous solution using bagasse and flyash, Waste Management and research, 22, pp.821-830.

[10] Yan, G., Viraraghavan, T., 2001, Heavy metal removal in a biosorption column by immobilized M.Rouxii biomass, Bioresource Technology, 78, pp.243-249.

[11] Malkoc, E., Nuhoglu, Y., 2005, Investigations of nickel (II) removal from aqueous solutions using tea factory waste, Journal of Hazardous Materials, 127, pp.120-128.

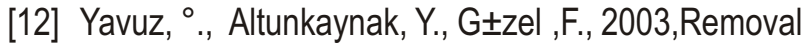
of copper, nickel, cobalt and manganese from aqueous solution by kaolinite, Water Research, 37,pp.948-952.

13] Ouki, S.K., Neufeld, R.D., 1997, Use of activated carbon for the recovery of chromium from industrial waste waters, Journal of Chemical Technology and Biotechnology, 70,pp.3-8.

[14] La Grega., Buckingham,M.D., Evans,P.L., 1994,Hazardous waste management, Mc GrawHill,1994,pp.859.

[15] Goyal, M., Ratan, V.K., Bansa R.C., 1999, Adsorption of nickel from aqueous solution by activated carbon, Indian Journal of Chemical Technology, 6,pp.305312.

[16] Benguella, B., Benaissa, H., 2002, Cadmium removal from aqueous solutions by chitin: Kinetic and equilibrium studies, Water Research, 36, pp.24632474.

[17] Calace, N., Nardi, B.E., Petronio, M., Pietroletti, M.,2002, Adsorption isotherm for describing heavy metal retention in paper mill sludges, Industrial and Engineering Chemistry Research, 41,pp.5491-5497.

[18] Cullen, G.V., Siviour, N.G., 1982, Removing metal from waste solutions with low rank coals and related materials, Water Research 16, pp.1357-1366.

[19] Farag, K., Perineau, F., Gaset, A., Moliniar. J., 1981, Adsorption of metal cations on wool carbonizing waste, Part I Adsorption, Journal of Chemical Technology and Biotechnology, 31, pp. 597-601.

[20] Abduli, M.A., Safari, E.,2002,Sorption of selected heavy metals in landfill leachate using rice husk, International Journal of Environmental Studies and Policy, 5,pp.1-10.

[21] Al-HajAli,A., El-Bishtawi, R., 1997, Removal of lead and nickel ions using Zeolite tuff, Journal of Chemical Technology and Biotechnology, 69, pp.27-34.

[22] Anoopkrishna, K., Aniruthan, T.S.,2002, Uptake of heavy metals in batch systems by sulfurised steam activated carbon prepared from sugarcane bagasse pith, Industrial and Engineering Chemistry Research,41,pp.5085-5093.

[23] Nuhoglu, Y., Malkoc, E., Gurses, A., Canpolat, N., 2002, The removal of $\mathrm{Cu}$ (II) from aqueous solutions by Ulothrix zonata, Bioresource Technology, 85,pp.331-333.

[24] Malkoc, E., Nuhoglu, Y., 2003, The removal of chromium (VI) from synthetic waste water by Ulothrix zonata, Fresenius Environmental Bulletin, 12, pp.376-381.

[25] Cheung, C.W., Porter, J.F., McKay, G., 2001, Sorption kinetic analysis for the removal of cadmium ions from effluents using bone char, Water Research, 35, pp.605-612

[26] Eligwe, C.A., Okolue, N.B., Nwambu, C.O., Nwoko, C.I.A., 1999, Adsorption thermodynamics and kinetics of mercury (II), cadmium (II) and lead (II) on lignite, Chemical Engineering and Technololgy, 22,pp.45-49. 
Anuradha S. et al: Adsorption of Nickel from Aqueous Solution by...

[27] Jeffrey, G.H., Bassett, J., Mendham, J., Denney, R.C., 1996, Vogel's textbook of quantitative chemical analysis, Newyork Wiley.

[28] Ajmal, M., Rao, R.A.K., Ahmad, R., Ahmad J., 2000, Adsorption studies on Citrus reticulata (fruit peel of orange): removal and recovery of $\mathrm{Ni}$ (II) from electroplating waste water, Journal of Hazardous Materials, 79, pp.117-131.

[29] ${ }^{\circ}$ zer , A., ${ }^{\circ}$ zer , D., ${ }^{\circ}$ zer A., 2004, The adsorption of Copper (II) ions on to dehydrated wheat bran (DWB): determination of equilibrium and thermodynamic parameters, Process Biochemistry, 39, pp.21832191.

[30] Aksu, Z., 2002, Determination of equilibrium, kinetic and thermodynamic parameters of batch biosorption of Nickel (II) ions onto Chlorella vulgaris, Process Biochemistry, 38, pp.89-99.
[31] Treybal, R.E., 1981, Mass transfer operations, Mc Graw Hill Publishers, $3^{\text {rd }}$ edition.

[32] Al-Rub, F.A., Kandah, M.,Aldabaibeh, N., 2002,Nickel removal from aqueous solutions using sheep manure wastes, Engineering in Life Science, 29,pp.111-116.

[33] Bayat, B., 2002, Comparative study of adsorption properties of turkish fly ashes. I. The case of nickel (II), copper (II) and zinc (II), Journal of Hazardous Materials, 95, pp.251-273.

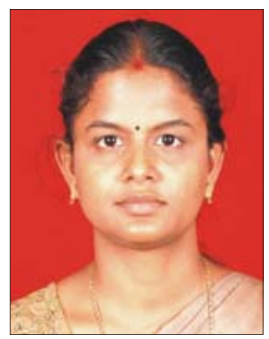

Ms. Anuradha.S is a Research Scholar and faculty in the Department of Biotechnology. She is pursuing her research in the field of Enzymology and Chemical technology 